\title{
INTERPRETASI EKONOMI HASIL ANALISIS STATISTIK MELALUI PENDEKATAN ELASTISITAS
}

\author{
Masyhuri \\ Jurusan Fakultas Pertanian Universitas Islam Malang (UNISMA) \\ Jln. MT. Haryono 193 Malang \\ Email: mashuri@fe.uin-malang.ac.id
}

\begin{abstract}
This paper aims to mendeskripasikan different interpretation of the results of the analysis ofthe value (unit) with a regression coefficient of elasticity values usingpercentage units (\%). Themethod of analysis using the descriptive approach of regression analysis of the roadmap research students of the Faculty of Economics State Islamic University(UIN) Malang Maulana Malik Ibrahim last five years (2005-2010). The results showed, that a researcher in interpreting the processed data is veryimportant 'unit' was wearing. If the interpretation of the results of the analysis used the word 'unit', then it is quite relevant to regression analysis. However, if the estimatoruses the word 'prosentse' (\%), it must use a mechanism of calculating the level of elasticity. On this basis, it is recommended to the reader or researcher the next, that the interpretation of the results though the use prosentse, the Cobb Douglas analysis is quite relevant because the coefficient has shown the level of elasticity.
\end{abstract}

Salah satu progres report Unit Penelitian dan Pengabdian Kepada Mayarakat (UP2M) tentang roadmap penelitian mahasiswa Fakultas Ekonomi Universitas Islam Negeri (UIN) Maulana Malik Ibrahim Malang lima tahun terakhir (2005-2010), hal yang perlu diperhatikan adalah interpretasi hasil analisis statistis sesuai dengan kaidah ekonomi. Ada beberapa model fungsi standar dalam analisis statistik, diantaranya adalah (i) fungsi linier sederhana atau ganda; $\mathrm{Y}=\mathrm{a}+\mathrm{b} \mathrm{X}_{\mathrm{i}}$; (ii) double $\log$ atau $\ln ; \log \mathrm{Y}=\log \mathrm{a}$ $+\mathrm{b} \log \mathrm{X}_{1}+\mathrm{c} \log \mathrm{X}_{2}+\ldots \mathrm{z}+\log \mathrm{X}_{\mathrm{n}}$; (iii) semi $\log ; \mathrm{Y}=\log \mathrm{a}+\mathrm{b} \log \mathrm{X}_{1}+\mathrm{c} \log \mathrm{X}_{2} ;$ (iv) $\log$ invest atau $\log$ linier $; \log \mathrm{Y}=\mathrm{a} \mathrm{b} \mathrm{X}_{1} / \mathrm{X}_{2}$. Masing-masing bentuk fungsi standar tersebut nilai koefisiennya tentu berbeda jika dilihat dari aspek elastisitasnya.

Berawal dari rumus elastisitas (e) secara umum, yaitu prosentase perubahan dependent variable akibat dari prosentase perubahan independent variable $\mathrm{e}=(\partial \mathrm{y} / \partial \mathrm{x})$ (x/y), maka nilai elastistanya adalah sebagai berikut: (dimana x dan y adalah rata-rata / aveage); (i) nilai elastisitas dari linier sederhana adalah $\mathrm{e}=\mathrm{b}(\mathrm{x} / \mathrm{y})$ dengan satuan 
prosentase; (ii) dari double $\log$ adalah $\mathrm{e}=\mathrm{b}$ yang berawal dari $\partial \log \mathrm{y} / \partial \log \mathrm{x}_{1}=\mathrm{b}\left(1 / \mathrm{x}_{1}\right)$ $(1 / \mathrm{y}) \partial \mathrm{y} / \partial \mathrm{x}=\mathrm{b}\left(1 / \mathrm{x}_{1}\right)$ jika disubstitusikan pada rumus elastisitas, maka nilai e $=\mathrm{b}\left(1 / \mathrm{x}_{1}\right)$ (y) $\left(\mathrm{x}_{1} / \mathrm{y}\right)$ sehingga $\mathrm{e}=\mathrm{b}$ jadi koefisennya sudah menunjukkan nilai elastisitas; (iii) nilai elastistas dari semi $\log$ adalah $\mathrm{e}=\mathrm{b} / \mathrm{y}$ derivasinya adalah $\partial \mathrm{y} / \partial \mathrm{x}_{1}=\mathrm{b}\left(1 / \mathrm{x}_{1}\right)$ jika disubstitusikan pada rumus elastisitas $\mathrm{e}=\mathrm{b}\left(1 / \mathrm{x}_{1}\right)\left(\mathrm{x}_{1} / \mathrm{y}\right)$ dan diperoleh $\mathrm{e}=\mathrm{b} / \mathrm{y}$ dan (iv) nilai elastisitas untuk $\log$ inverst atau $\log$ linier adalah $\mathrm{e}=\mathrm{b}\left(\mathrm{x}_{1} / \mathrm{x}_{2}\right)$ derivasinya adalah $\partial \log y / \partial \log x_{1}=b\left(1 / x_{2}\right)$ diperoleh $(1 / y) \partial y / \partial x=b\left(1 / x_{2}\right)$ sehingga $\partial y / \partial x=b\left(y / x_{2}\right) j i k a$ disubstitusikan pada rumus elastisitas, maka $\mathrm{e}=\mathrm{b}\left(\mathrm{y} / \mathrm{x}_{2}\right)\left(\mathrm{x}_{1} / \mathrm{y}\right)$ akhirnya $\mathrm{e}=\mathrm{b}\left(\mathrm{x}_{1} / \mathrm{x}_{2}\right)$.

Roadmap riset mahasiswa di Fakultas Ekonomi UIN akan diidentifikasi pada variabel yang dominan dan berpengaruh secara nyata dalam analisis regresinya menunjukkan demikian, tetapi kenyataan $90 \%$ sering terjadi kurang tepat pengggunaan satuan prosentase $(\%)$ dalam interpretasi ekonominya sehingga perlu ada kajian ulang dalam rangka menempatkan satuan yang betul-betul tepat dengan mengkomperasian antara hasil analisis regresi sederhana (OLS) dengan hasil analisis Cobb Douglas. Tujuan Penelitian ini adalah untuk mendeskripasikan secara jelas dan mendalam komperasi interpretasi (interpretation) hasil analisis dari nilai (satuan) koefisien regresi dengan nilai elastisitas yang memakai satuan prosentase (\%).

\section{METODE}

Metode penentuan data; penelitian ini memanfaatkan data sekunder (time series) yaitu roadmap riset hasil penelitian di FE UIN Maliki perode 2005-2010 dari kosentrasi pemasaran. Metode analisisnya menggunakan 3 pendekatan, yaitu pendekatan regresi linier berganda, elastisitas dan pendekatan Cobb-Douglas. Khusus untuk pendekatan selengapnya akan dijelaskan secara rinci karena teori ini hasil analisis koefisien regresinya telah menunjukkan tingkat elastisitasnya.

Fungsi produksi homogen dengan derajat satu bersifat constant return to scale. Kalau $\mathrm{f}(\mathrm{mK}, \mathrm{mL})>\mathrm{mY}$ disebut increasing return to scale. Kalau $\mathrm{f}(\mathrm{mK}, \mathrm{mL})<\mathrm{mY}$ disebut decreasing return to scale. Khusus pada kasus fungsi produksi Cobb-Douglas : $\mathrm{Y}=\mathrm{Ak}^{\alpha} \mathrm{L}^{1-\alpha}$ bersifat konstan return to scale $\alpha=\mathrm{w}_{\mathrm{k}}=$ elastisitas produksi modal $(1-\alpha)=$ $\mathrm{wL}=$ elastisitas produksi tenaga kerja. Bentuk umum fungsi produksi tipe Cobb Douglas adalah $\mathrm{Y}=\mathrm{A}_{\mathrm{x} 1}^{\mathrm{b} 1} \times 2^{\mathrm{b} 2} \ldots \ldots \ldots \mathrm{x}_{\mathrm{n}}{ }^{\mathrm{bn}}$ dimana $\mathrm{bi}=\mathrm{wi}=$ eslisitas produksi $\mathrm{xi}$ dan 
$\sum_{i=1}^{n} b i=1$ disebut constant return to scale

$\sum_{i=1}^{n} b i<1$ disebut decreasing return to scale dan fungsi produksi concave

$\sum_{i=1}^{n} b i>1$ disebut increasing return to scale dan fungsi produksi convex

Bukti bahwa di dalam fungsi produksi Cobb Douglas nilai koefisien regresi adalah tingkat elastisitas produksi $\left(\mathrm{E}_{\mathrm{p}}\right)$

Bentuk yang paling sederhana $\mathrm{Y}=\mathrm{a} \mathrm{X}^{\mathrm{b}}$

Rumus elastisitas $=\mathrm{Ep}=\frac{d Y}{d X} \cdot \frac{X}{Y}$

$$
\begin{aligned}
\frac{d Y}{d X} & =\mathrm{f}_{1}=0 \\
& =\mathrm{bAX}^{\beta-1} \\
& =\beta \frac{Y}{X}
\end{aligned}
$$

jadi Ep $=\beta \frac{Y}{X} \cdot \frac{X}{Y} \quad$ sehingga diperoleh $\quad \mathrm{E}_{\mathrm{p}}=\beta$ (terbukti)

Demikian nilai dari $\mathrm{E}_{\mathrm{p}}$ adalah sama dengan 1 (satu), pembuktiannya sebagai berikut:

Fungsi expantansi path $\frac{f_{1}}{f_{2}}=\frac{r_{1}}{r_{2}}$

$\mathrm{f}_{1} \quad=\beta \mathrm{AX}_{1}{ }^{\mathrm{B}-1} \mathrm{X}_{2}^{\alpha}$

$\mathrm{f}_{1=} \quad=\beta \frac{Y}{X_{1}}$

$\mathrm{f}_{2} \quad=\alpha \mathrm{AX}_{2}^{\alpha-1}$

$\mathrm{f}_{2} \quad=\alpha \frac{Y}{X_{2}}$.

Saat substitusi $1,2,3$

$\frac{\beta \frac{Y}{X_{1}}}{\alpha \frac{Y}{X_{2}}}=\frac{r_{1}}{r_{2}}$

$\frac{\beta X_{2}}{\alpha X_{1}}=\frac{r_{1}}{r_{2}} \quad$ dimisalkan: Misalkan $\frac{X_{2}}{X_{1}}=\mathrm{Y} \quad$ dan $\quad \frac{r_{1}}{r_{2}}=\mathrm{X}$, maka: 
$\frac{Y}{X}=\frac{\alpha}{\beta} \quad$ dan $\quad \mathrm{X} / \mathrm{Y}=\frac{\beta}{\alpha} \quad$ jika disubstitusikan pada elastisitas produksi $\left(\mathrm{E}_{\mathrm{p}}\right)$ sehingga akan diperoleh:

$$
\begin{aligned}
\mathrm{E}_{\mathrm{P}} & =\frac{\partial Y / Y}{\partial X / X} \quad \text { secara sederhana dapat dilakukan sebagai berikut: } \\
& =\frac{\partial\left(\frac{\mathrm{x}_{2}}{\mathrm{x}_{1}}\right)}{\frac{\mathrm{x}_{2}}{\mathrm{x}_{1}}} \frac{\mathrm{f}_{1} / \mathrm{f}_{2}}{\partial\left(\mathrm{f}_{1} / \mathrm{f}_{2}\right)} \quad \mathrm{E}_{\mathrm{p}}=[\mathrm{dy} / \mathrm{dx}][\mathrm{x} / \mathrm{y}]=\frac{\alpha}{\beta}: \frac{\beta}{\alpha}=1 \\
& =\frac{\partial\left(\frac{\mathrm{x}_{2}}{\mathrm{x}_{1}}\right)}{\left[\frac{\mathrm{r}_{1}}{\mathrm{r}_{2}}\right]} \cdot \frac{\mathrm{r}_{1} / \mathrm{r}_{2}}{\mathrm{x}_{2} / \mathrm{x}_{1}} \\
& =\frac{\alpha}{\beta}: \frac{\beta}{\alpha}=1 \text { (terbukti) }
\end{aligned}
$$

\section{HASIL DAN PEMBAHASAN}

Beberapa hasil penelitian yang dilakukan mahasiswa Fakultas Ekonomi UIN Maulana Malik Ibrahim Malang atas dasar roadmap hasil penelitian (skripsi) berikut ini hasilnya: (1) Penelitian A. Zainul Ihsan (2005), yaitu Pengaruh leverage keuangan terhadap pendapatan per lembar saham biasa, menunjukkan hasil yang sebagai berikut: Setelah dilakukan pengolahan terhadap data yang diperoleh dengan menggunakan SPSS for Windows Release 11.00, maka diperoleh persamaan model regresi sebagai berikut:

$$
Y(\text { hat })=13776,270+19812,636 X_{1}-0,0000000253 X_{2}-66812,4 X_{3}+e
$$

$\mathrm{Y}($ hat $)=$ Prediksi pendapatan per lembar saham biasa (Earning per Share - EPS)

$\mathrm{X}_{1}=$ Debt to Equity Ratio (DER); $\mathrm{X}_{2}=$ beban bunga hutang $; \mathrm{X}_{3}=$ Degree of Financial Leverage (DFL); e = kesalahan/pengganggu.

Interpretasi hasil penelitian tersebut dengan satuan yang ada; (i) jika factor Debt to Equity Ratio (DER) naik sebesar satu - satuan, maka keputusan berwisata akan naik terjadi kenaikan. Apabila kenaikan tersebut diukur dengan angka numerik, maka naiknya sebesarnya 19812,636 satu - satuan. Hasil analisis menunjukkan bahwa koefisien regresi DER sebesar 19812,636 dapat diartikan jika DER naik sebesar satu satuan, maka EPS akan naik sebesar 19812,636 satuan, dimana variabel independen lainya konstan (Ceteris 
Paribus); (ii) jika faktor Beban Bunga Hutang naik sebesar satu - satuan, maka keputusan berwisata akan turun sebesar 0,0000000253 satu - satuan. Koefisien regresi beban bunga sebesar -0,0000000253 dapat diartikan jika beban bunga naik sebesar 1 satuan, maka EPS akan turun sebesar 0,0000000253 satuan, dimana variabel independen lainnya konstan dan (iii) jika faktor Degreeof Financial Leverage (DFL) naik sebesar satu - satuan, maka keputusan berwisata akan turun sebesar 66812,4 satu - satuan. Hal ini ditandai dengan nilai koefisien regresi DFL sebesar -66812,4.

Interpretasi dengan pendekatan nilai elastisitas - menginterpretasikan hasil analisis tersebut dengan pendekatan konsep elastisitas dari masing - masing variabel independent, maka perlu diketahui nilai rata-rata $X_{1}$ rata - rata sebesar 1,30450, rata-rata $X_{2}$ sebesar 1,4, rata-rata $\mathrm{X}_{3}$ sebesar 0,5283 , dan rata-rata $\mathrm{Y}$ sebesar 778,88770, sehingga elastisitasnya dapat dihitungan sebagai berikut:

$$
\mathrm{e}=\left(\partial \mathrm{y} / \partial \mathrm{x}_{1}\right)\left(\mathrm{x}_{1} / \mathrm{y}\right)=19812,636(1,30450 / 778,88770)=33,1827
$$

Interpretasinya adalah jika DER naik sebesar $1 \%$ maka keputusan berinvestasi naik sebesar 33,1827 \% demikian juga proses perhitungan selanjutnya untuk $\mathrm{x}_{2}$ dan $\mathrm{x}_{3}$ sama. Jadi apabila dalam interpretasi melalui prosesntase TIDAK-lah diperkenankan untuk menginterpretasikan seperti ini; "jika DER naik sebesar 1\% maka keputusan berinvestasi naik sebesar 1981263,6 \% - dan in-feasible".

Penelitian Reny Indri Martanti (2008), judul penelitian adalah "Analisis Variabelvariabel yang Pada Tingkat Harga Saham di Indeks Jakarta Islamic Index (JII) Periode 20042008". Penelitian yang dilakukan merupakan penelitian kuantitatif dengan model regresi linier berganda yaitu analisis yang digunakan besar dan arah pengaruh dari satu atau lebih variabel bebas (variabel independen) terhadap satu variable tak bebas (variabel dependen). Variabel independen dalam penelitian ini adalah EPS, PER, ROE dan ROA. Sedangkan variabel dependen yang digunakan adalah harga saham, yang diolah menggunakan SPSS, dengan hasil sebagai berikut: 
Coefficients

\begin{tabular}{|c|c|c|c|c|c|c|}
\hline \multirow{2}{*}{\multicolumn{2}{|c|}{ Model }} & \multicolumn{2}{|c|}{$\begin{array}{c}\text { Unstandardized } \\
\text { Coefficients }\end{array}$} & \multirow{2}{*}{$\begin{array}{c}\text { Standardized } \\
\text { Coefficients } \\
\text { Beta } \\
\end{array}$} & \multirow[b]{2}{*}{$\mathrm{t}$} & \multirow[b]{2}{*}{ Sig. } \\
\hline & & $\mathrm{B}$ & Std. Error & & & \\
\hline \multirow[t]{5}{*}{1} & (Cons tant) & $-11798,9$ & 2495,908 & & $-4,727$ &, 000 \\
\hline & EPS & 6,359 &, 964 & ,517 & 6,597 &, 000 \\
\hline & PER & 904,833 & 139,758 & ,711 & 6,474 & ,000 \\
\hline & ROE & 25,500 & 53,195 & ,039 & , 479 & ,639 \\
\hline & $\mathrm{ROA}$ & 164,996 & 127,427 & ,146 & 1,295 & ,215 \\
\hline
\end{tabular}

a. Dependent Variable: Harga Saham

Dan menghasilkan persamaan regresi sebagai berikut:

$$
Y=-11798,9+6,359 x_{1}+904,833 x_{2}+25_{y} 5 x_{3}+164_{z}, 996 x_{4}
$$

Intepretasi atas persamaan regresi; (i) pada saat variabel independen (EPS, PER, ROE, dan ROA) dalam keadaan konstan maka Y (harga saham) berada pada posisi 11798,9 satuan; (ii) EPS (Earning per Share), artinya ketika EPS meningkat 1 satuan, maka harga saham meningkat sebesar 6,359 satuan atau dengan kata lain pengaruh EPS teradap harga saham adalah positif; (iii) PER (Price Earning Ratio), artinya ketika PER meningkat 1 satuan, maka harga saham meningkat sebesar 904,833 satuan. Besarnya koefisien regresi PER ini, menunjukkan bahwa PER merupakan variabel yang memiliki pengaruh dominan terhadap harga saham; (iv) ROE (Return of Investment), artinya ketika ROE meningkat 1 satuan, maka harga saham meningkat sebesar 25,5 satuan dan (v) ROA (Return of Asset), artinya ketika ROA meningkat 1 satuan, maka harga saham meningkat sebesar 164,996 satuan.

Analisis Elastisitas dan Intepretasinya; (i) elatisitas EPS $\left(\mathrm{x}_{1}\right)$, hasilnya sebesar $E=6,359 \cdot \frac{926,89}{9096.69}=0,577$ artinya ketika EPS mengalami kenaikan sebesar $1 \%$ maka akan mempengaruhi kenaikan harga saham sebesar $0,577 \%$; (ii) elatisitas PER $\left(\mathrm{x}_{2}\right)$, hasilnya sebesar $E=904,833 \cdot \frac{12,4 \pi}{9096,69}=1,236$ artinya ketika PER mengalami kenaikan sebesar $1 \%$ maka akan mempengaruhi kenaikan harga saham sebesar 1,236 \% ; (iii) elatisitas ROE $\left(\mathrm{x}_{3}\right)$, hasilnya sebesar $E=25,5 \times \frac{40,89}{9096,69}=0,11459$ artinya pada saat ROE mengalami kenaikan sebesar $1 \%$ maka akan mempengaruhi kenaikan harga saham sebesar $0,11459 \%$; (iv) elatisitas ROA $\left(\mathrm{x}_{4}\right)$, hasilnya sebesar $E=164,996 \cdot \frac{20,29}{9096,69}=0,368$ artinya pada saat ROA mengalami kenaikan sebesar $1 \%$ maka akan mempengaruhi kenaikan harga saham sebesar 0,368 1\% 
Penelitian dari Siti Khodijah (2010), judul penelitian: Analisis Kinerja Keuangan Perusahaan Terhadap Return Saham Di Bursa Efek Indonesia (Study pada Perusahaan yang Masuk Kategori Indeks LQ-45 di Bursa Efek Indonesia). Para investor sangat berkepentingan terhadap kinerja keuangan yang akan dicapai oleh suatu perusahaan dimana mereka akan melakukan investasi. Hal tersebut dikarenakan melalui penilaian sukses tidaknya perusahaan dalam mengelola atas modal kerja yang telah dimilikinya. Karena melalui penilaian kinerja keuangan maka akan diketahui stabilitas serta kontinuitas atau kelangsungan perusahaan.

Analisis laporan keuangan mencakup dua hal yaitu perbandingan kinerja keuangan perusahaan dengan kinerja keuangan perusahaan lain pada industri yang sama dan merupakan suatu evaluasi trend posisi perusahaan selama beberapa waktu (Brigham, 1995: 70). Rasio-rasio kinerja keuangan itu sendiri saling berhubungan dan saling mempengaruhi. Bila rasio-rasio likuiditas perusahaan manajemen aktiva, manajemen hutang, dan profitabilitas baik, maka rasio nilai pasar juga akan tinggi, dan harga sahamnya akan memiliki nilai yang tinggi seperti yang diharapkan (Brigham, 1995:82)

Hubungan kinerja keuangan dengan return saham bersifat searah, dan rasio-rasio keuangan menujukkan kinerja keuangan dari perusahaan tersebut. Kinerja keuangan yang baik akan meningkatkan nilai dari perusahaan itu di mata investor. Investor sendiri cenderung lebih menyukai perusahaan-perusahaan yang memiliki kinerja keuangan yang baik. Dan bila permintaan akan saham itu meningkat maka investor dapat memperoleh return dalam bentuk capital gain.

Untuk mengukur pengaruh kinerja keuangan perusahaan terhadap perubahan harga saham, peneliti menggunakan variabel PER, ROE dan EPS. Beberapa definisi operasional variabel DOV) adalah sebagai berikut: (i) variabel terikat (dependent, Y) adalah return saham yang merupakan tingkat pengembalian yang diharapkan dari saham dan (ii) variabel bebes (independent, $\mathrm{X}_{\mathrm{i}}$ ) yang terdiri dari: Price Earning Ratio (PER, $\mathrm{X}_{1}$ ) Rasio ini membandingkan antara harga saham dengan EPS dan Rasio On Equity (ROE, $\mathrm{X}_{2}$ ) Rasio ini adalah rasio yang mengukur pengembalian nilai buku kepada pemilik perusahaan. 
Earning Per Share (EPS, $\left.\mathrm{X}_{3}\right)$, rasio ini merupakan rasio yang menunjukkan pendapatan yang diperoleh untuk setiap lembar selama satu periode. Pengukuran statistic sampel dalam penelitian ini dilakukan dengan menggunakan program komputer Statistical Package for Sosial Science (SPSS) 12 dengan hasil perhitungan sebagai berikut:

$$
\mathrm{Y}=4,496-0,185 \mathrm{X}_{1}-0,011 \mathrm{X}_{2}+0,110 \mathrm{X}_{3}+\mathrm{e}
$$

Interpretasinya dari Persamaan Regresi - konstanta, nilai konstanta dari persamaan regresi ini sebesar 4,496 menyatakan bahwa jika tidak ada variabel PER, ROE dan EPS, maka return saham sebesar 4,496. Sedangkan koefesien Variebel $X_{1}$ (PER), nilai dari koefesien regresi $\mathrm{X}_{1}$ sebesar -0,185 menyatakan bahwa apabila PER naik satu-satuan maka return saham akan turun 0,185 satuan. Koefesien variebel $\mathrm{X}_{2}(\mathrm{ROE})$, nilai dari koefesien regresi $\mathrm{X}_{2}$ sebesar $-0,011$ menyatakan bahwa apabila ROE naik satu-satuan maka return saham akan turun 0,011 satuan.

Koefesien variebel $\mathrm{X}_{3}$ (EPS), nilai dari koefesien regresi $\mathrm{X}_{2}$ sebesar 0,110 menyatakan bahwa apabila PER naik satu-satuan maka return saham akan naik 0,110 satuan. Interpretasi tersebut jika diinterpretasikan dalam prosentase, maka perlu dilakukan analisis elastisitas. Analisis elastisitas dan interpreasinya: mekanisme perhitungan analisis elastisitas, komponen yang diperlukan adalah rata-rata dari masing-masing variable yang terlibat dalam model yang telah disusun oleh peneliti, diantaranya; (i) rata-rata $\mathrm{Y}=$ 3,7124 , rata-rata $X_{1}=3,944$, rata-rata $X_{2}=5,5796$ dan rata-rata $X_{3}=0,324 . \quad E_{1}=$ $\frac{\Delta y}{\Delta x} x \frac{X}{Y}=-0,185(3,944 / 3,7124)=-0,1967$ artinya jika PER $\left(\mathrm{x}_{1}\right)$ naik $1 \%$, maka return Saham (y) akan turun $0,1967 \%$; (ii) $\mathrm{E}_{2}=\frac{\Delta y}{\Delta x} x \frac{X}{Y}=-0,011(5,5796 / 3,7124)=-$ 0,0165 artinya jika ROE ( $\mathrm{x}_{2}$ ) naik 1\%, maka return saham (y) akan turun 0,0165\% dan (iii) $\mathrm{E}_{3}=\frac{\Delta y}{\Delta x} X \frac{X}{Y}=0,110(0,324 / 3,7124)=0,0096$ jika EPS $\left(\mathrm{x}_{3}\right)$ naik $1 \%$, maka return saham $(\mathrm{Y})$ akan naik $0,0096 \%$.

Nuzularul Rohmah (2008), Analisis Elastisitas Pada Skripsi Yang Berjudul Pengaruh Perilaku Kosumen Terhadap Keputusan Berwisata Di Wisata Bahari Lamongan (WBL). Hasil penelitian menunjukkan: $Y=2,245+0,471 X_{1}+0,693 X_{2}+0,276 X_{3}+0,021 X 4$ 
dengan penjelasan $\mathrm{Y}$ : keputusan berwisata ; $\mathrm{X}_{1}$ : faktor budaya $; \mathrm{X}_{2}$ : faktor sosial; $\mathrm{X} 3$ : faktor pribadi X4: faktor psikologi.

Interpretasi hasil penelitian tersebut dengan satuan yang ada; (i) jika faktor budaya menjadi satu perhatian yang dijadikan sebagai salah satu factor dalam menentukan akses pada wisatwan, maka keputusan berwisata cenderung didorong oleh aspek budaya - jika di ukur dengan angka satuan numeric, maka budaya akan mendorong kenaikan keputusan berwisata di WBL naik sebesar 0,471 satu - satuan; (ii) jika faktor sosial menjadi pertimbangan dalam berwisata, maka akan mendorong untuk memutuskan wisata ke WBL - analisis angka numeriknya dapat dijelaskan bahwa kenaikan status sosial satu satuan, maka keputusan berwisata akan naik sebesar 0,693 satu - satuan; (iii) jika faktor pribadi wisatawan jadi variabel yang mempengaruhi, maka akan mendorong untuk memutuskan wisata ke WBL. Demikian juga analisis angka numerik, bahwa kenaikan satu satuan, akan menyebabkan kenaikan angka numeric sebesar 0,276 satu - satuan ; dan (iv) jika faktor psikologi jadi pertimbangan dalam akses wisata WBL, maka akan mendorong keputusan wisata. Dengan demikian analisis numeric adalah kenaikan satu satuan dari aspek psikologi, maka keputusan berwisata akan naik sebesar 0,021 satu satuan.

Analisis elastisitas - Interpretasi hasil analisis tersebut dengan pendekatan konsep elastisitas dari masing - masing variabel independent. Diketahui $\mathrm{x}_{1}$ rata - rata sebesar 8,$5667 ; \mathrm{x}_{2}$ rata - rata 8,$1500 ; \mathrm{x}_{3}$ rata - rata 11,$7833 ; \mathrm{x}_{4}$ rata - rata 11,8833 dan $\mathrm{Y}$ rata rata sebesar 8,1000. (i) $\mathrm{e}_{\mathrm{x} 1}=0,471(8,5667 / 8,10)=0,498$; (ii) $\mathrm{e}_{\mathrm{x} 2}=0,693(8,150 / 8,10)$ $=0,69 ;$;iii) $\mathrm{e}_{\mathrm{x} 3}=0,276(11,7833 / 8,10)=0,405 ;$ (iv) $\mathrm{e}_{\mathrm{x} 4}=0,021(11,8833 / 8,10)=0,03$ Interpretasinya sebagaimana sebelumnya.

Hasil Analisis dengan Pendekatan Cobb Douglas - Hasil ini diambil dari bimbingan skripsi yang sedang menyusun draf laporan penelitian yaitu atas nama Maria Ulfa (07510024) dari jurusam manajemen Faklutas Ekonomi UIN Maliki. Hasil analisis sebagai berikut: (1) Pengaruh sales promotion, variabel kesadaran merek, (i) koefisien determinan $\left(\mathrm{R}^{2}\right)$, sebesar 0,86 yang berarti bahwa variasi pengaruh variabel independent terhadap variabel dependent sebesar $86 \%$ sedangkan $14 \%$ dipengaruhi oleh variabel lain yang tidak dimasukkan dalam model. Adjusted R square sebesar 0,721 yang sering 
dipakai adalah Adjusted $\mathrm{R}$ square ini; (ii) Uji Anova (Analysis of Varians) atau Uji F nilainya sebesar F hitung adalah 36,292 dengan tingkat signifikansi 0,000. Sedangkan F tabel pada taraf $5 \%$ adalah 2,92. Oleh karena $F_{\text {hitung }}>F_{\text {tabel }}$ yaitu 36,292 >2,92 dan tingkat signifikansinya $0,000<0,05$ menunjukkan bahwa variabel independent terhadap variabel dependent secara simultan(serentak) berpengaruh secara nyata (significant) dan (iii) Uji secara Parsial atau Uji t.

Berdasarkan hasil analisis bahwa $\ln \mathrm{Y}=0,150+0,081 \ln \mathrm{x}_{1}+0,331 \ln \mathrm{x}_{2}+$ $0,472 \ln x_{3}$ interpretasinya adalah; (catatan; ln dan log adalah sama); (i) konstanta ( $\alpha$ ) sebesar 0,150 hal tersebut mempunyai arti bahwa variabel sales promotion, variabel kesadaran merek, dan variabel isi pesan dianggap konstan maka keputusan pembelian non makanan (Y) sebesar 0,150; (ii) Elastisitas variabel sales promotion $\left(\mathrm{x}_{2}\right)$ terhadap keputusan pembelian produk non makanan tidak berpengaruh secara nyata terhadap keputusan pembelian. Hal tersebut terlihat dari adanya nilai signifikansi 0,158>0,05 dan $\mathrm{t}_{\text {hitung }}<\mathrm{t}_{\text {tabel }}$ yaitu sebesar 1,438<2,042 karena $\mathrm{t}_{\text {hitung }}$ lebih kecil dari $\mathrm{t}_{\text {tabel }}$ maka hipotesis Ho diterima dan menolak $\mathrm{Ha}$, yang berarti tidak berpengaruh secara signifikan; (iii) Elastisitas variabel kesadaran mereka $\left(\mathrm{x}_{3}\right)$ terhadap keputusan pembelian produk non makanan sebesar 0,331 yang berarti bahwa jika total keputusan pembelian produk non makanan naik sebesar 1\%, maka rata-rata kesadaran merek untuk keputusan pembelian produk non makanan akan naik sebesar 0, 331\%. Jadi kesadaran merek untuk non makanan berpengaruh secara signifikan terhadap keputusan pembelian. Hal tersebut terlihat dari adanya nilai signifikansi $0,000<0,05$ dan $t_{\text {hitung }}>t_{\text {tabel }}$ yaitu sebesar 7800 $>2,042$ karena $t_{\text {hitung }}$ lebih besar dari $t_{\text {tabel. }}$.

Variabel Minuman (Y3); (i) koefisien Determinasi $\mathrm{R}^{2}=0,933$ dan Adjusted $\mathrm{R}$ square sebesar 0,933 hal tersebut berarti bahwa elastisitas dari variabel promosi, variabel isi pesan, variabel label, variabel kemasan, variabel ungkapan visual, variabel merek, dan variabel sumber pesan yang mempengaruhi keputusan pembelian produk makanan sebesar 93,3\% dan sisanya yaitu sebesar 6,7\% dapat dijelaskan oleh faktor-faktor lain yang tidak dijelaskan dalam penelitian ini; (ii) Uji Secara Simultan (Uji F), sebesar 82,491 dengan tingkat signifikansi 0,000. Sedangkan $\mathrm{F}$ tabel pada taraf $5 \%$ adalah 2,33. Oleh karena $F_{\text {hitung }}>F_{\text {tabel }}$ yaitu $36,292>2,33$ dan tingkat signifikansinya $0,000<0,05$ 
menunjukkan bahwa pengaruh variabel promosi, variabel isi pesan, variabel label, variabel kemasan, variabel ungkapan visual, variabel merek, dan variabel sumber pesan secara serentak adalah signifikan terhadap keputusan pembelian produk non makanan; (iii) Uji secara parsial (Uji t), di mana hasil analisis selengkapnya dapat diformulasikan sebagai berikut:

$\ln \mathrm{Y}=\ln 0,223+0,009 \ln \mathrm{x}_{1}+0,032 \ln \mathrm{x}_{2}+0,006 \ln \mathrm{x}_{3}+0,189 \ln \mathrm{x}_{4}+0,201 \ln$ $\mathrm{x}_{5}+0,284 \ln \mathrm{x}_{6}+0,127 \ln \mathrm{x}_{7}$

Maka persamaan tersebut dapat digambarkan sebagai berikut: (i) konstanta $\alpha$ sebesar 0,223 hal tersebut mempunyai arti bahwa variabel promosi, variabel isi pesan, variabel label, variabel kemasan, variabel ungkapan visual, variabel merek, dan variabel sumber pesan dianggap konstan maka keputusan pembelian minuman (Y) sebesar 0,233; (ii) Elastisitas variabel merek $\left(\mathrm{x}_{1}\right)$ terhadap keputusan pembelian produk minuman sebesar 0,009. Variabel merek untuk minuman tidak berpengaruh secara signifikan terhadap keputusan pembelian. Hal tersebut terlihat dari adanya nilai signifikansi $0,480>0,05$ dan $t_{\text {hitung }}<t_{\text {tabel }}$ yaitu sebesar 0,714<2,042 karena $t_{\text {hitung }}$ lebih kecil dari $t_{\text {tabel }}$ maka hipotesis Ho diterima dan menolak Ha; (iii) Elastisitas variabel kemasan $\left(\mathrm{x}_{2}\right)$ terhadap keputusan pembelian produk minuman sebesar 0,032.

Variabel kemasan untuk minuman tidak berpengaruh secara signifikan terhadap keputusan pembelian. Hal tersebut terlihat dari adanya nilai signifikansi 0,082>0,05 dan $t_{\text {hitung }}<t_{\text {tabel }}$ yaitu sebesar $1,793<2,042$ karena $t_{\text {hitung }}$ lebih kecil dari $t_{\text {tabel }}$ maka hipotesis Ho diterima dan menolak Ha; (iv) Elastisitas variabel label $\left(\mathrm{x}_{3}\right)$ terhadap keputusan pembelian produk minuman sebesar 0,006. Variabel kemasan untuk minuman tidak berpengaruh secara signifikan terhadap keputusan pembelian. Hal tersebut terlihat dari adanya nilai signifikansi $0,778>0,05$ dan thitung $<_{\text {tabel }}$ yaitu sebesar $0,285<2,042$ karena thitung lebih kecil dari ttabel maka hipotesis Ho diterima dan menolak Ha; (v) elastisitas variabel sumber pesan $\left(\mathrm{x}_{4}\right)$ terhadap keputusan pembelian produk minuman sebesar 0,189 yang berarti bahwa jika total keputusan pembelian produk minuman naik sebesar $1 \%$, maka rata-rata kesadaran sumber pesan untuk keputusan pembelian produk minuman akan naik sebesar $18,9 \%$. Sumber pesan untuk minuman berpengaruh secara signifikan terhadap keputusan pembelian. Hal tersebut terlihat dari adanya nilai signifikansi 
$0,000<0,05$ dan $t_{\text {hitung }}>t_{\text {tabel }}$ yaitu sebesar 8,907>2,042 karena $t_{\text {hitung }}$ lebih besar dari $t_{\text {tabel }}$ maka hipotesis Ho ditolak dan menerima Ha; (vi) Elastisitas variabel isi pesan $\left(\mathrm{x}_{5}\right)$ terhadap keputusan pembelian produk minuman sebesar 0,201 yang berarti bahwa jika total keputusan pembelian produk minuman naik sebesar $1 \%$, maka rata-rata kesadaran sumber pesan untuk keputusan pembelian produk minuman akan naik sebesar $0,2,1 \%$.

Jadi, isi pesan untuk minuman berpengaruh secara signifikan terhadap keputusan pembelian, yang dibuktikan nilai signifikansi $0,000<0,05$ dan $t_{\text {hitung }}>t_{\text {tabel }}$ yaitu sebesar $10,761>2,042$ karena $t_{\text {hitung }}$ lebih besar dari $t_{\text {tabel }}$ maka hipotesis Ho ditolak dan menerima $\mathrm{Ha}$; (vii) Elastisitas variabel ungkapan visual $\left(\mathrm{x}_{6}\right)$ terhadap keputusan pembelian produk minuman sebesar 0,284 yang berarti bahwa jika total keputusan pembelian produk minuman naik sebesar 1\%, maka rata-rata kesadaran ungkapan visual untuk keputusan pembelian produk minuman akan naik sebesar $0,284 \%$.

Ungkapan visual untuk minuman berpengaruh secara signifikan terhadap keputusan pembelian dengan nilai signifikansi $0,000<0,05$ dan $t_{\text {hitung }}>t_{\text {tabel }}$ yaitu sebesar 9,320>2,042 karena $t_{\text {hitung }}$ lebih besar dari $t_{\text {tabel }}$ maka hipotesis Ho ditolak dan menerima $\mathrm{Ha}$ (viii) Elastisitas variabel promosi $\left(\mathrm{x}_{7}\right)$ terhadap keputusan pembelian produk minuman sebesar 0,127 yang berarti bahwa jika total keputusan pembelian produk minuman naik sebesar $1 \%$, maka rata-rata ungkapan visual untuk keputusan pembelian produk minuman akan naik sebesar $0,127 \%$ dengan nilai signifikansi $0,000<0,05$ dan $t_{\text {hitung }}>t_{\text {tabel }}$ yaitu sebesar 4,401>2,042 karena $t_{\text {hitung }}$ lebih besar dari $t_{\text {tabel }}$.

\section{KESIMPULAN DAN SARAN}

\section{Kesimpulan}

Kesimpulan pembahasan di muka adalah sebatas pada interpretasi 'bahasa' artinya dari angka hasil olah satatistik ke interpretasi ekonomi dengan satuan prosentase, dan hasil interpretasi tidak dikaitkan dengan teori yang ada; (ii) Peneliti (researcher) dalam menginterpretasikan data hasil olahan sangat penting 'satuan' yang dipakainya, maka hal ini cukup relevan dengan untuk analisis regresi; (iii) Jika researcher menggunakan kata 'prosentse' (\%), maka harus menggunakan mekanisme perhitungan tingkat elastisitas dan/atau menggunakan pendekatan cobb douglas. 


\section{Saran}

Dari hasil pembahasan di atas, maka saran yang dapat direkomendasikan sebagai berikut: apabila pembaca atau peneliti (researcher) berikutnya melakukan interpretasi hasil olah yang menggunakan prosentse, maka analisis cobb douglas yang cukup relevan karena koefisiennya telah menunjukkan tingkat elastisitasnya.

\section{PUSTAKA}

Ari Sudarman, (1991). Ekonomi Mikro-Makro. (Teori, soal dan jawaban). Yogyakarta: BPFE.

Bambang, S., (1990). Matematika untuk Ekonomi, Jakarta: penerbit Erlangga.

Bronson, R., (1982). Theory and Problems of Operations Research. McGraw-Hill, Inc., USA.

Cochran,WG.,(1953). Sampling Techniques. 2d ed. New York: John Wiley and Sons, Inc.

Chambers,R.G. (1988). Applied Production Analysis. A dual approach, Cambridge University Press.

Chiang,A.C., (1974). Fundamental of Mathematical Economics.

Deming,W.E., (1960). Sample Design in Business Research. New York: John Wiley and, Inc.

Henderson,J.M., and R.E.Quandt. (1980). Microeconomic Theory: A Mathematical Approarch. Mc.Graw-Hill International Book co.

Jogiyanto, H., (1999). Teori Ekonomi Mikro Analisis Mataematis. Yogyakarta: Andi Affset.

Masyhuri (2007). Teori Ekonomi Mikro. Malang: UIN Press.

Masyhuri (2006). Pengantar Ekonomi Mikr. Jakarta : Pretasi.

Maryatmo, (200). Ilmu Ekonomi Mikro, Yogyakarta: Andi Offset.

Koutsoyiannis,A. (1982). Modern Microeconomics, Hongkong: The MacMillan Press. Ltd., Second Edition.

Landis, John, D., (1995). Imagining Land Use Futures: Applying The California Urban Futures Model. Journal Of The American Planning Association (AIP) ISSN:0194-4363 Vol.:61 Iss: 4 Date Autumn 1995 p:438-457.

Masyhuri, (1996). Pola Alokasi Tenaga Kerja Keluarga Dalam Menunjang Perekonomian Rumah Tangga pada Daerah Pengembangan Kawasan Industri. DIKTI. No.116/P2IPT/DPPM/LITMUD/1996.

-------, (1998). Studi Kelayakan Mendirikan Cold Storage (CS) dan Milk Treatmen (MT) pada Beberapa Koperasi Unit Desa (KUD) Produsen Susu Sapi Perah di Kab. Malang. DIKTI. No.130/P21PT/DPPM/98 LITMUD/V/1998.

-------, (1998). Pemberdayaan Masyarakat Pedesaan pada Industrialisasi Pedesaan sebagai Upaya Menanggulangi Kemiskinan dalam Rangka Menghadapi Era Globalisasi. Penelitian Hibah Bersaing, DIKTI. No.75/P21PT/PHB/VII-1/V/1999. (tahun I). 
------, (1999). Pemberdayaan Masyarakat Pedesaan pada Industrialisasi Pedesaan sebagai Upaya Menanggulangi Kemiskinan dalam Rangka Menghadapi Era Globalisasi. Penelitian Hibah Bersaing, DIKTI. No.044/P21PT/HB/VII-2/1999. (tahun II).

-------, (2002). Analisis Perencanaan Sumberdaya Yang Optimal. Disertasi S-3. Surabaya: Program Studi Ilmu Ekonomi Pembangunan PPS UNAIR Surabaya.

Mendenhall,W.,Ott,L.,Scheaffer,L.R.,(1971). Elementary Survey Sampling. University of Florida. California : Duxbury Press A Division of Wad Sworth Publishing Company, Inc. Belmon.

Mize,J.H. and J.G.,Cock, (1968). Essential of Simulation. New Jersey : Prentice Hall Inc., Englewood-Cliffs.

Data Pendukung:

1) Data hasil analisis saudari Maria Ulfa (07510024) penelitian yang menggunakan Pendekatan Teori Cobb Douglas.

2) Tulisan ini dihimpun dari tugas mahasiswa semester VI angkatan 2007 FE UIN Maliki pada matakuliah Ekonomi Manajerial tahun ajaran Gasal 2010/2011.

3) Roadmap Penelitian Mahasiswa FE UIN Maliki Periode 2005-2010. Unit Penelitian dan Pengabdian Kepada Masyarakat (UP2M). 